\title{
Orphans in Three Sahelian Countries: Exploratory Analyses from Census Data
}

\author{
Richard Marcoux, \\ Université Laval \\ Québec City, Québec, Canada \\ E-mail: Richard.Marcoux@soc.ulaval.ca \\ Amadou Noumbissi, \\ Tukufu Zuberi, \\ University of Pennsylvania \\ Philadelphia, Pennsylvania, USA
}

\begin{abstract}
Important investments in Africa have reduced slightly the levels child mortality but life expectancy still very low. The number of children without surviving biological parents is increasing and orphans are becoming an important social problem. Because Sahelian societies are mostly patriarchal, becoming fatherless or motherless will have different effects on the well being of the child. This paper examines the levels and trends of the survival status of the parents and then, living arrangements of orphans. We describe characteristics of these children with a special focus on education and economic activities. The paper uses the censuses from Chad, Niger and Senegal made available by the African Census Analysis Project (ACAP) held at University of Pennsylvania. These countries collected information on survival status of each biological parent to estimate adult mortality but the potential of this information for research on child well-being is rarely exploited.
\end{abstract}

Key Words: Childhood, orphan, Africa, census data, family demography 


\section{Résumé}

Des investissements importants dans les secteurs de la santé et des services sociaux en Afrique ont largement contribué à réduire la mortalité des enfants au cours des dernières années mais paradoxalement, dans certaines régions, on aurait assisté à une diminution de l'espérance de vie. La conséquence logique de ce double phénomène est une augmentation du nombre d'orphelins. Or, dans les sociétés patriarcales du Sahel, le fait de perdre son père ou sa mère peut avoir des effets différents. Cet article examine d'abord les niveaux et les tendances de la survie des parents selon l'âge des jeunes et s'intéresse ensuite à l'éducation et à la mise au travail des enfants et ce, selon qu'ils sont orphelins ou non. L'ensemble des analyses repose sur le traitement des données de recensements rendues accessibles dans le cadre du Programme d'analyse des recensements africains de l'Université de Pennsylvanie et ce, pour trois pays sahéliens: le Sénégal, le Niger et le Tchad. Des questions sur la survie de chacun de parents ont été prévues dans les questionnaires de recensements de ces pays. Ces informations sont habituellement utilisées uniquement pour estimer la mortalité adulte alors que cet article révèle les potentialités d'analyse de ces informations pour caractériser les conditions sociales des orphelins en Afrique.

Mots clés: Enfance, orphelin, Afrique, données de recensements, démographie de la famille

\section{Introduction}

A large part of the socio-historic literature on childhood and orphans is dedicated to the processes of institutionalization (Koven and Michel 1993; Crenson 1998; Lee 2002; Turmel 2008). Childhood as a social subject and as an object of specific interventions appeared in the West during the $18^{\text {th }}$ and $19^{\text {th }}$ centuries and was primarily associated with a preoccupation with social regulation. Faced with vagrancy and heightened crime levels among young people who had been abandoned or left alone, public powers and religious charitable organizations instituted various measures to better support young people left on their own. The opening of orphanages was only one of numerous measures toward this end-other steps included the opening of reform schools and trade schools, as well as judicial interventions leading to better support of children who found themselves without a family. Taking responsibility for children was part of a larger process of institutionalization of childhood. Still,

CSP 2010, 37.1-2: 245-267 
Orphans in Three Sahelian Countries:

Exploratory Analyses from Census Data

children left alone following the death of their parents were for the most part reintegrated into the extended family by living with a brother, an uncle or aunt, etc. (Légaré and Dufford 2001; Murray 2003; Crenson 1998).

In sub-Saharan Africa, placing children in institutions is a marginal practice compared with the importance of the extended family safety net (McDaniel and Zulu 1996; Foster 2002; Case et al. 2002). In fact, there is hardly any institutionalization of orphans to speak of in sub-Saharan Africa. Of course, there are some young people in the street and many abandoned children, but their number is relatively small in relation to the total number of children without parents, although it has seen substantial growth in some countries. Nevertheless, in the particular case of orphans, that is, children who have lost at least one of their biological parents, there is no doubt that African family networks currently act as a social safety net for these young people, fitting in with the fostering practices that are widespread in Africa (Foster 2002; McDaniel and Zulu 1996).

An interest in orphans in Africa has recently developed in the literature on childhood; this interest is largely tied to the progression of the AIDS pandemic (Caldwell 1997; Hunter and Williamson 1999 and 2000; Quinn 2001). A brief bibliographic search on the topic of orphans in Africa in Pop Index, Sociofile, and Francis (an index of francophone sociological journals) confirms this connection; $75 \%$ of the works that have appeared since 1985 on this topic deal with the phenomenon of orphans in Africa in the context of the AIDS pandemic. The phenomenon of orphans in Africa nevertheless substantially predates the AIDS pandemic, and it is astonishing that the social dimensions of this reality lived by many young Africans have not attracted more attention from the scientific community interested in childhood.

In the countries of the Sahel, where the AIDS pandemic is much less severe than elsewhere in Africa, the issue of orphanhood seems for this reason to have been even less well researched. Still, the number of children who have lost a parent is very large-as we will see-due in part to the levels of adult mortality in the region. The available information on three demographic parameters suggests that the number of orphans is not only large, but even growing, in the countries of the Sahel. First, child mortality has fallen substantially over the last 20 years: the most recent data have made it possible to estimate a decline in child mortality of more than $25 \%$ in Mali since the early 1980s (Bah and Singare 2002) and of close to $20 \%$ in Chad (Barrère and Barrère 1998) and Burkina Faso (Mboup 1998). Secondly, although we are able to estimate it with much less precision, adult mortality has also fallen, but the decline is much smaller than that of child mortality. The most recent work using DHS data on the countries of the Sahel seems to show that rates of adult mortality (15 to 49 years old) are still relatively high and are on average at levels about $50 \%$ higher than the levels estimated using indirect methods (Ayad 2002; Sullivan and Barrère 1993). Thirdly, since the most recent studies show that fertility levels have not declined

CSP 2010, 37.1-2: 245-267 
for 30 or 40 years and now remain close to 7 children per woman (Njoniri 1998; Coulibaly and Singare 2002), we can deduce that these countries now count a larger proportion of children who outlive their parents at young ages.

The objective of this article is twofold. We propose first to estimate the number and the proportion of orphans among children and young people under age 25 in the Sahel. In the second part, we will attempt to distinguish subsets of children grouped according to the survival of their parents in order to examine some of their specific characteristics. One branch of the literature emphasizes the importance of social ties in African societies. Families represent a sort of social safety net for individuals in difficulty, thus making up for the absence of social programs and public institutions for orphan children. Other authors, however, think that the extent and persistence of the social, economic, and political crises that have struck African societies are leading to an erosion of the mechanisms of solidarity, provoking important processes of exclusion of certain elements of the population. It might therefore be fruitful to examine certain characteristics of the "orphans" found in households and to compare these characteristics to those of children who have not experienced the death of a parent. We will examine here two dimensions of what might be called the process of social insertion of young people in the Sahel: education and work. This exploratory study of orphans in the Sahel allows us to identify several paths for future research on what will become of children and young people, while also demonstrating the analytic potential of African census data made available through ACAP.

\section{Data and Methods}

We note that in the western socio-historic literature, orphans are often defined solely as the clientele of orphanages, which might suggest an evolution in the definition of the concept of orphan (Crenson 1998). An orphan is a "child deprived by death of one or usually both parents." However, orphanages, despite their names, often took in children whose parents were still alive and could not (or did not want to) take responsibility for them. Murray (2003), for example, judges that two thirds of the orphans in the Charleston Orphan House between 1790 and 1860 had been taken to the institution by their father and/or their mother. The definition that we will retain here is one that is closer to the one we usually think of: an orphan is a person at least one of whose biological parents is dead.

We use micro-data from the 1988 Senegal, 1988 Niger and 1993 Chad. In these censuses, questions were asked about the survival status of biological parents of each household member. Due to the lack of data for estimating adult mortality in African countries, the survival status of parents were exclusively used to estimate levels, trends and patterns of adult mortality using indirect

CSP 2010, 37.1-2: 245-267 
methods (Brass and Hill 1973; Hill and Trussell 1997; Timaeus 1992, 1993; Bah 1999). The proportions of children with living parents are transformed into adult probability of survival by using equations established by Brass and Hill (1973), Hill and Trussell (1977) and Timaeus (1992). This technique assumes that every person knows his or her biological mother and father and is able to report accurately on their survival status. Unfortunately, the household head is the only respondent during the census data collection, increasing the risk of errors. Even though the question may be clearly asked on the biological parents, false answers may occur when the child is fostered or adopted. In our case study, all the three countries are characterized by a very low proportion of children with parental survival status unknown: less than $0.5 \%$ of children aged 24 and below are in this situation. Given the low level of unknowns, we have dropped from our analysis all the cases with unknown or missing parental survival status.

Because of the increasing number of orphans due to the HIV/AIDS impact on Africa, parental survival status collected in census and surveys is being used to study the orphanage and its impact on school enrollment and economic activities (Case et al. 2002, Bicego et al. 2003). Most of these studies use survey data characterized by the problem of small sample size. Information on the survival status of parents along with individual, household, and community characteristics available in most African censuses give us the leverage to examine in-depth levels, differentials and spatial variation of parental survival as well as the well-being of orphans.

Some drawbacks of this approach should be pointed out. Both census and survey data are cross-sectional and the date of the parent death is unknown. Also, street children and children living in institutions such as orphanages are generally not covered by the census. This study considers the orphan prevalence to be equal to the proportion of children by age with father, mother or both parents reported dead (Bicego et al. 2003). We divide children into four mutually exclusive categories according to the reported survival status of their parents: Mother dead and father alive (mother only or maternal orphans); Father dead and mother alive (father only or paternal orphans); both parents dead (double orphans); both parents alive (non-orphans). To estimate the extent of the range of the observed differences by selected variables and compare the school attendance and the labor force participation of children in relation with the survival status of their parents, we first use simple odds and odds ratios to examine association between school attendance, labor force participation and survival status of parents. Considering the social reality in theses countries, especially the laws governing school attendance and labor force participation, we have distinguished three broad age groups for school attendance (0-6, 7-14 and 15-24) and labor force participation (10-14, 15-19 and 20-24). 


\section{Orphans in the Sahel}

As expected, the proportion of children with at least one or both parents reported dead increases with age. For all the three countries, there exist important differences between reported mother-only dead and father-only dead. At all ages, the proportion of children reporting their father dead is higher than the proportion of children reporting their mother dead. While more than 30 percent of persons aged between 35 and 40 years have reported the death of their fatheronly, less than 10 percent of persons of the same age groups reported the death of their mother-only.

The large differences between father and mother are not simple cultural or data artifacts, but are due to both higher male mortality and differences in the age at childbearing between men and women: in all these countries, men tend to marry later than women and are usually married to younger women.

Considering the main purpose, Figure 1 limits the comparison of different functions between the three countries to under age 25. It appears that at all ages the survival status of fathers is higher in Senegal than in Niger and Chad which seem to have the same level of survival status of fathers. The proportion of mothers reported dead appears higher in Niger than in Senegal and Chad. The comparison of the Niger and Senegal is more accurate; comparing Senegal and Niger to Chad requires taking into account the 5 year difference between census dates (the three censuses refer to two different dates, 1993 for Chad and 1988 for Senegal and Niger).

Table 1 summarizes some parental survival status indicators. More than 5 percent of children aged 14 and below are declared fatherless in Chad while this proportion 4.2 percent in Niger and about 3.5 percent in Senegal. More than 7 percent of children aged 14 and below have lost at least one parent in Chad and Niger compared to 6.7 in Senegal. More than 4 percent of children aged 24 and below are declared motherless in Niger while less than 3 percent of children are in this situation in Chad and Senegal. The high number of fatherless in Chad is probably the consequence of the various wars in this country struggled with about 5 years before the 1993 Census. On the other hand, the highest number of motherless children in Niger needs an in-depth investigation since the three countries have approximately the same levels of maternal mortality and life expectancy. Between 1995 and 2000 the female life expectancies at birth are 54, 50 and 49 respectively in Senegal, Niger and Chad (United Nations 2000).

CSP 2010, 37.1-2: 245-267 
Orphans in Three Sahelian Countries: Exploratory Analyses from Census Data

Figure 1

Parental Suvival Status in Niger, Senegal and Chad
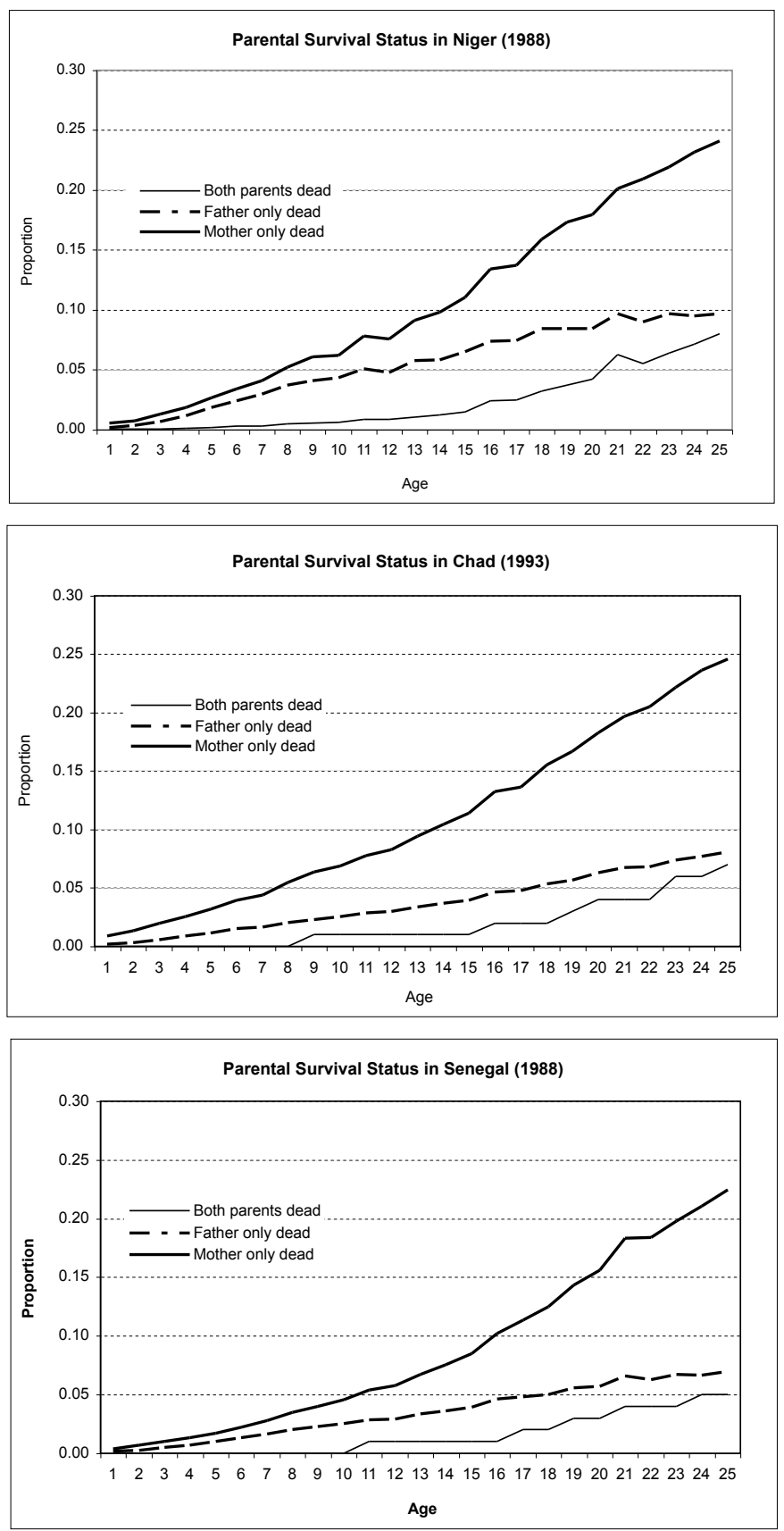

Source: Computed from 1993 Chad, 1988 Niger and Senegal census micro-data. 


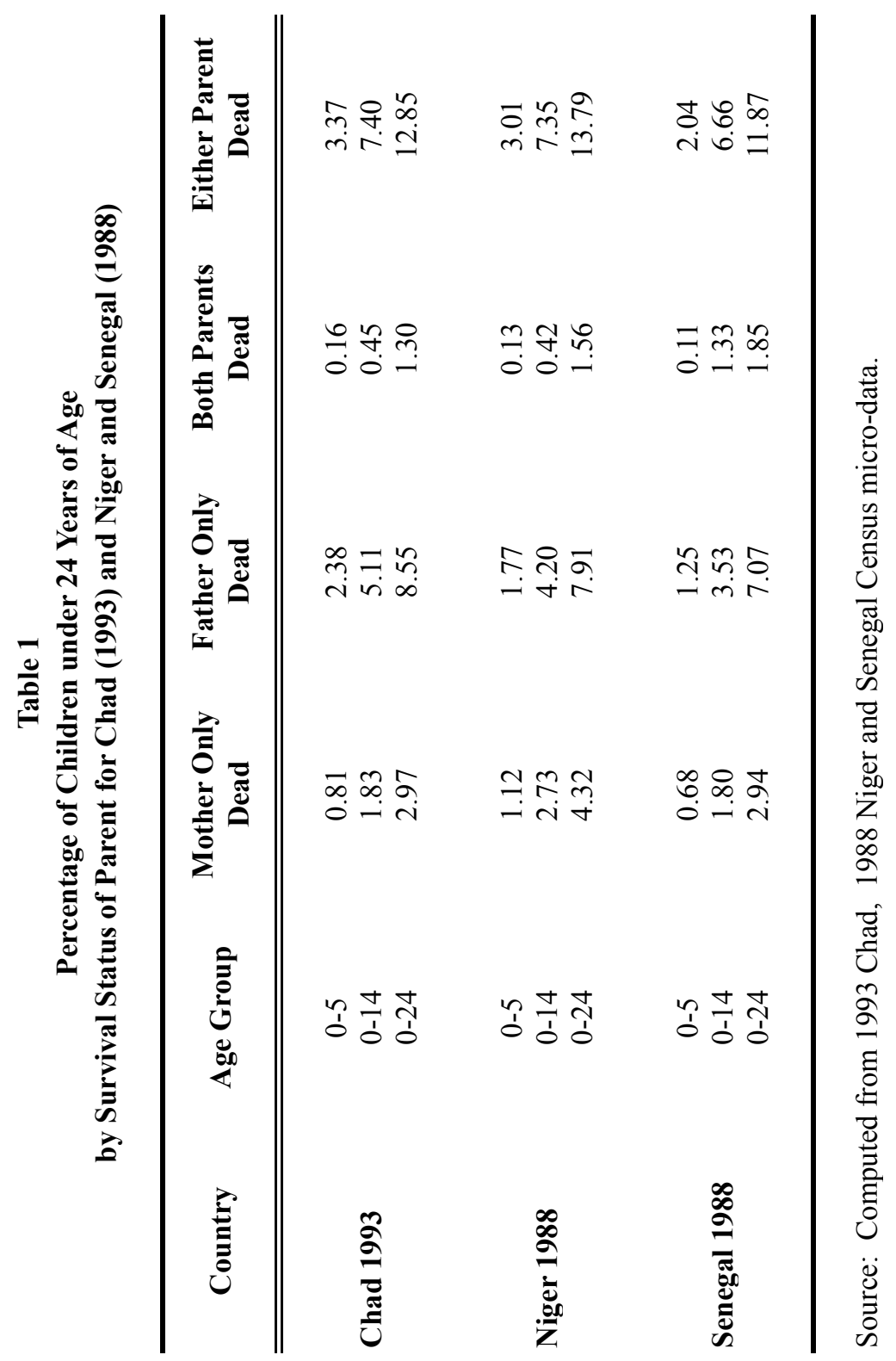




\section{Relationship to the Household Head and Parental Survival Status ${ }^{2}$}

Tables 2 and 3 present, for Niger and Senegal, the percentage of children under age 25 by relationship to household head and group ages. The death of a parent leads to the dislocation of the system and the family environment caring for a child. Especially the death of both parents creates new conditions that may participate to the relief of the trauma due to the loss of parents or emphasize the poor conditions of orphans children.

The type of household where the orphans reside influences their wellbeing. For example, some research has shown that schooling of orphans depends largely on the degree of the relationship between the orphan and the household head (Case et al. 2002). Residing with a relative such as grandparents, uncle/aunt or a sibling may not benefit the orphans the same way as residing alone or with a non-related person. The variable relationship to the household head is used here to identify the persons with whom orphan children reside.

As expected, a vast majority of children are enumerated children of the head when both parents are alive. The proportions of children living with their parents decrease with the age of the child due to the increase number of children leaving their parents' household to create their own household by marriage (especially girls) or becoming head of the household. In Niger more than 7 percent of boys between ages 15 and 24 are already head of household and this proportion passes to more than 22 percent when both parents are dead. Only about 1.5 percent of Senegalese boys between ages 15 and 24 are head of the household and this increases to 7 percent when both parents are dead. For the girls more than 46 percent in Niger and 21 percent in Senegal aged between 15 and 24 are enumerated as spouse of the household head when both parents are alive. These percentages increased to more than 54 in Niger and 43 in Senegal when both parents are reported dead. This result suggests the precociousness and the high levels of nuptiality among girls in Niger and at a relatively lower scale in Senegal, especially when both parents are reported dead.

Most of the children with both parents dead are residing in households headed by their relatives and in few cases with non-related household head. For example, when both parents are reported dead, more than 90 percent of Senegalese children under age 15 are residing in a household headed by a relative. For Niger, this proportion is more than 72 percent for boys and about 65 percent for girls. A significant percentage of children reside in a household headed by a non-related person, especially in Niger, when both parents are dead: about 12 percent of boys under 25 and more than 18 percent of girls from Niger compared to less than 10 percent and less than 6 percent for Senegalese boys and girls respectively. 


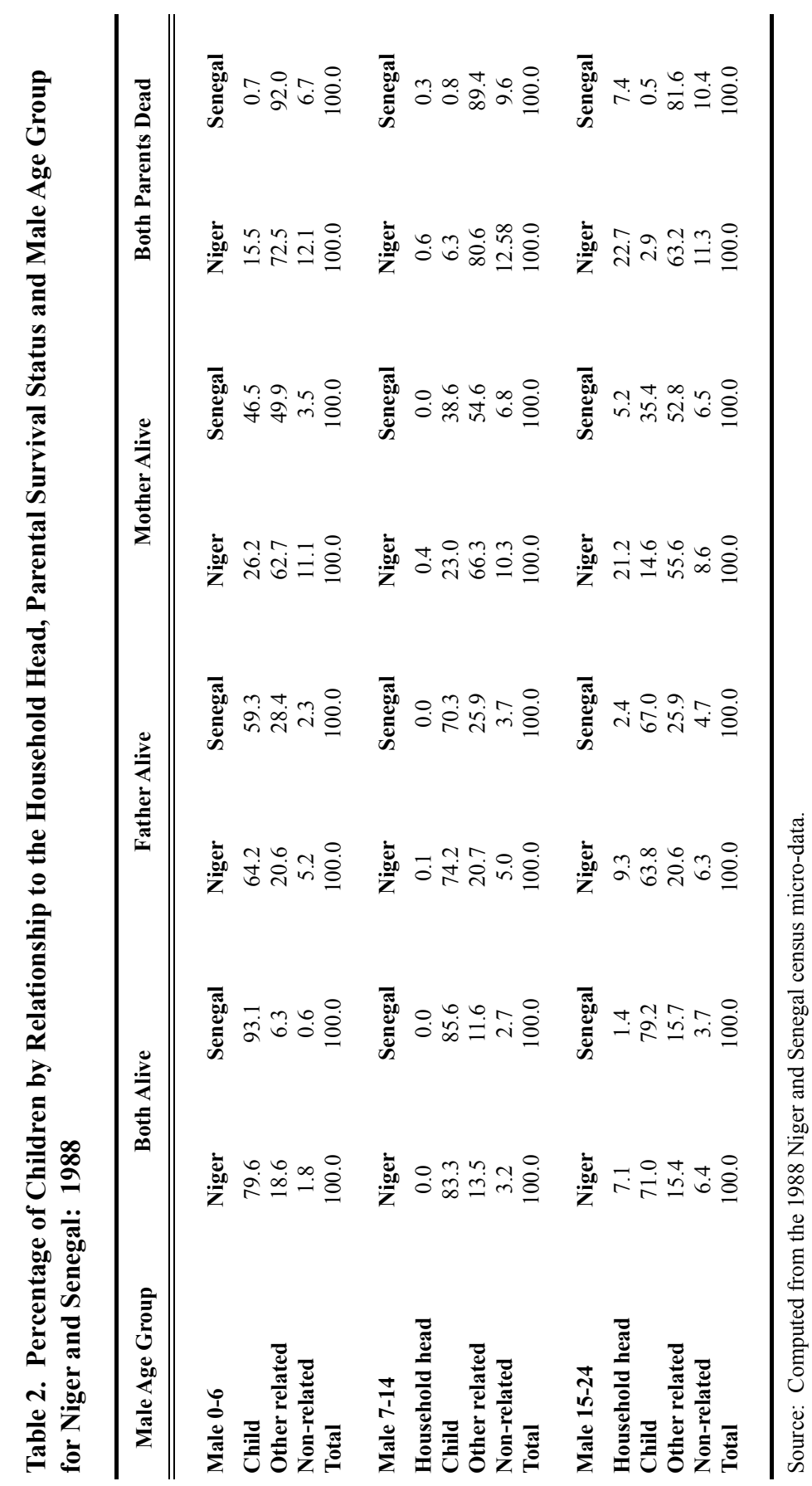

CSP 2010, 37.1-2: 245-267

254 


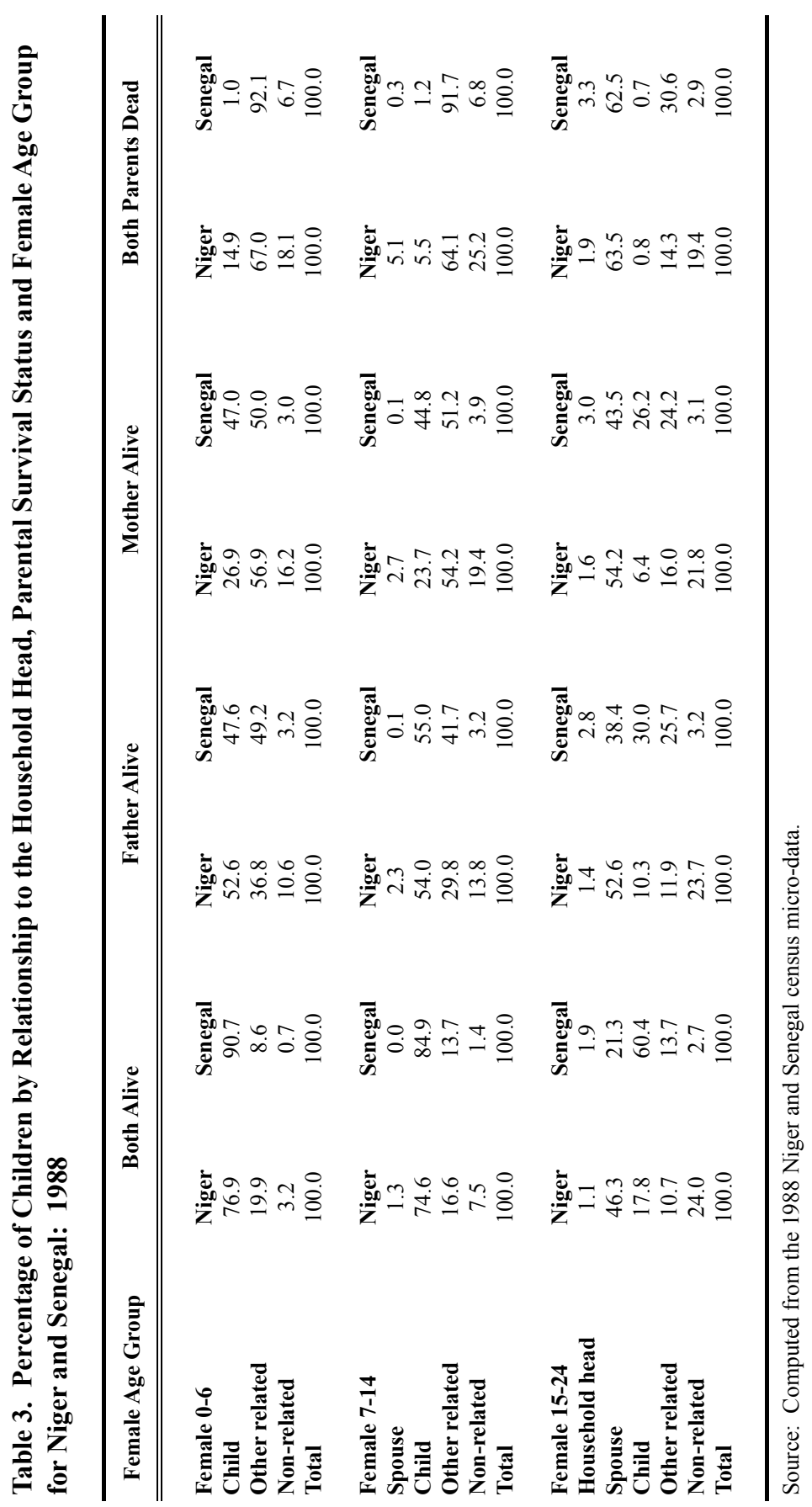


Finally, we must emphasize that young female orphans in Niger who have lost both parents are more likely than male orphans to live in households where no family tie links them to the head of household: this proportion reaches $25 \%$ between ages 7 and 14 for girls compared to $13 \%$ for boys of the same age.

\section{School Attendance and Labour Force Participation}

Low levels of school attendance is acute in Sahelian Countries: it is so acute that it is referred to the Sudano-Sahelian illiteracy belt (Antonielli 1993). The countries of the Sahel have primary education rates that are among the lowest in the world; this phenomenon is lowest for girls (Marcoux 1998). A recent study using life history reports taken from 3,000 children allowed us to estimate that more than $65 \%$ of children 12 to 16 years old in 2000 in rural areas of Mali had never gone to school (more than $70 \%$ of girls taken alone). Education for all by the year 2010 represents a considerable challenge for the countries of the Sahel (Marcoux et al. 2002).

School attendance represents an important element in the economic integration of young people, we examine whether academic capital is evenly distributed among children and young people, especially with respect to the survival of parents. The census data give us the highest level of education attained for each person enumerated. We first look at the proportions of those who have ever attended school by age. The data presented in figures 2 allow us to observe differences in school attendance varying between 10 and 20 percentage points between those who have lost both parents and those who have not lost any; maternal and paternal orphans are situated between these two groups. In summary, those excluded from school are over-represented among orphans.

Table 4 present age group and education level. In Niger, $25 \%$ of young boys age 7 to 14 have been to primary school, as opposed to $13 \%$ of double orphans. The proportion of those who have reached a level beyond primary school is twice as high among non-orphans as among double orphans. The same trends are observed for girls. In summary, as others have observed, the loss of one or both parents seems to have a considerable influence on children's academic career (Case et al. 2002; Marcoux et al. 2002; Wakam 2002).

As we have already underlined, interest in the problem of low school attendance too often leads us to overlook its corollary: children's early entry into the work force (Marcoux 1994 and 1997). Census data, although not ideal for capturing certain subtleties of African labor markets, nevertheless give us several indicators of participation in economic activity. The censuses of the countries examined here collected information on the activities of young people starting at age 6 in Senegal and age 10 in Niger. For boys, we note here that

CSP 2010, 37.1-2: 245-267 
Orphans in Three Sahelian Countries:

Exploratory Analyses from Census Data
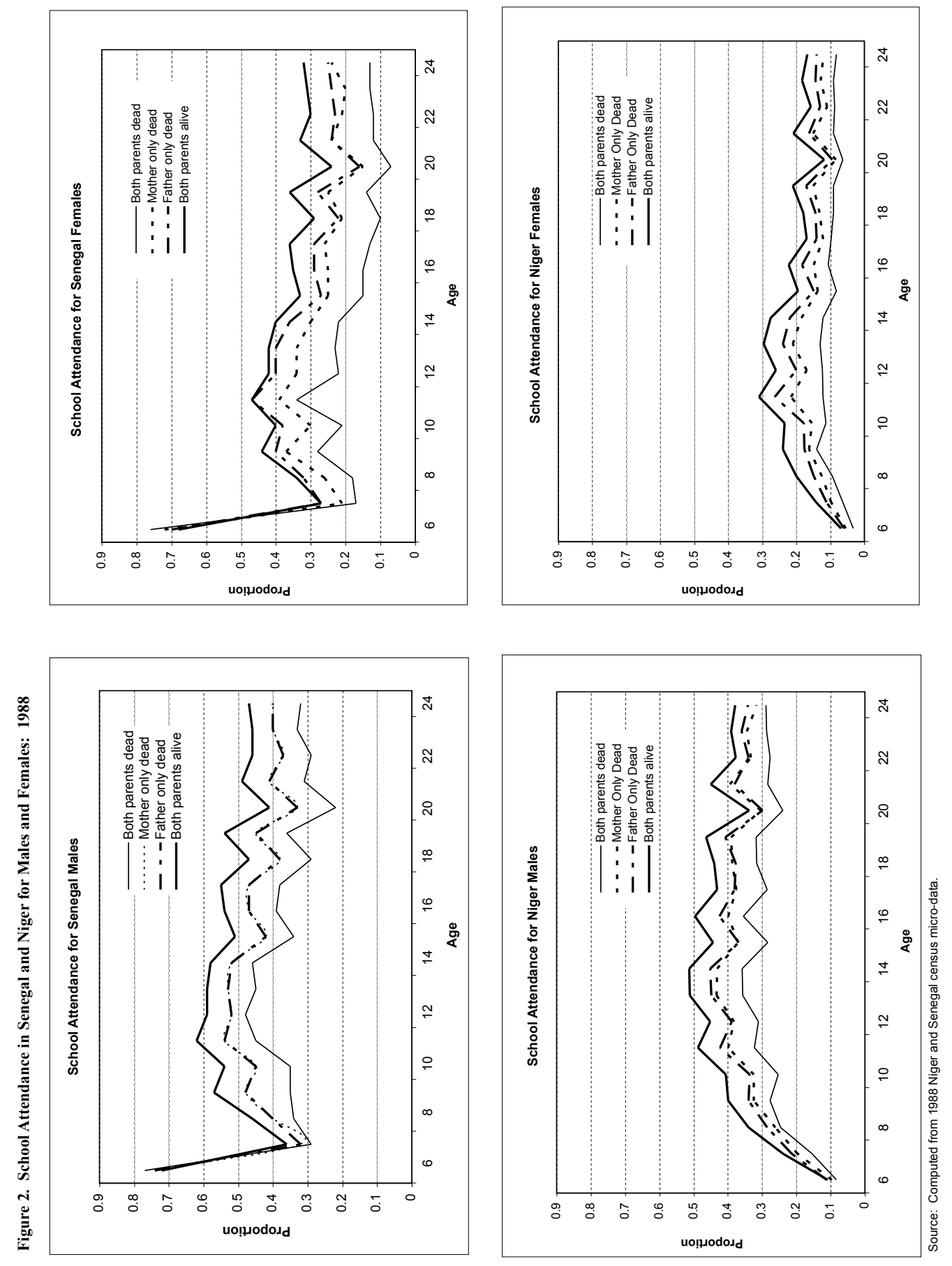

CSP 2010, 37.1-2: 245-267

257 
Richard Marcoux, Amadou Noumbissi and Tukufu Zuberi
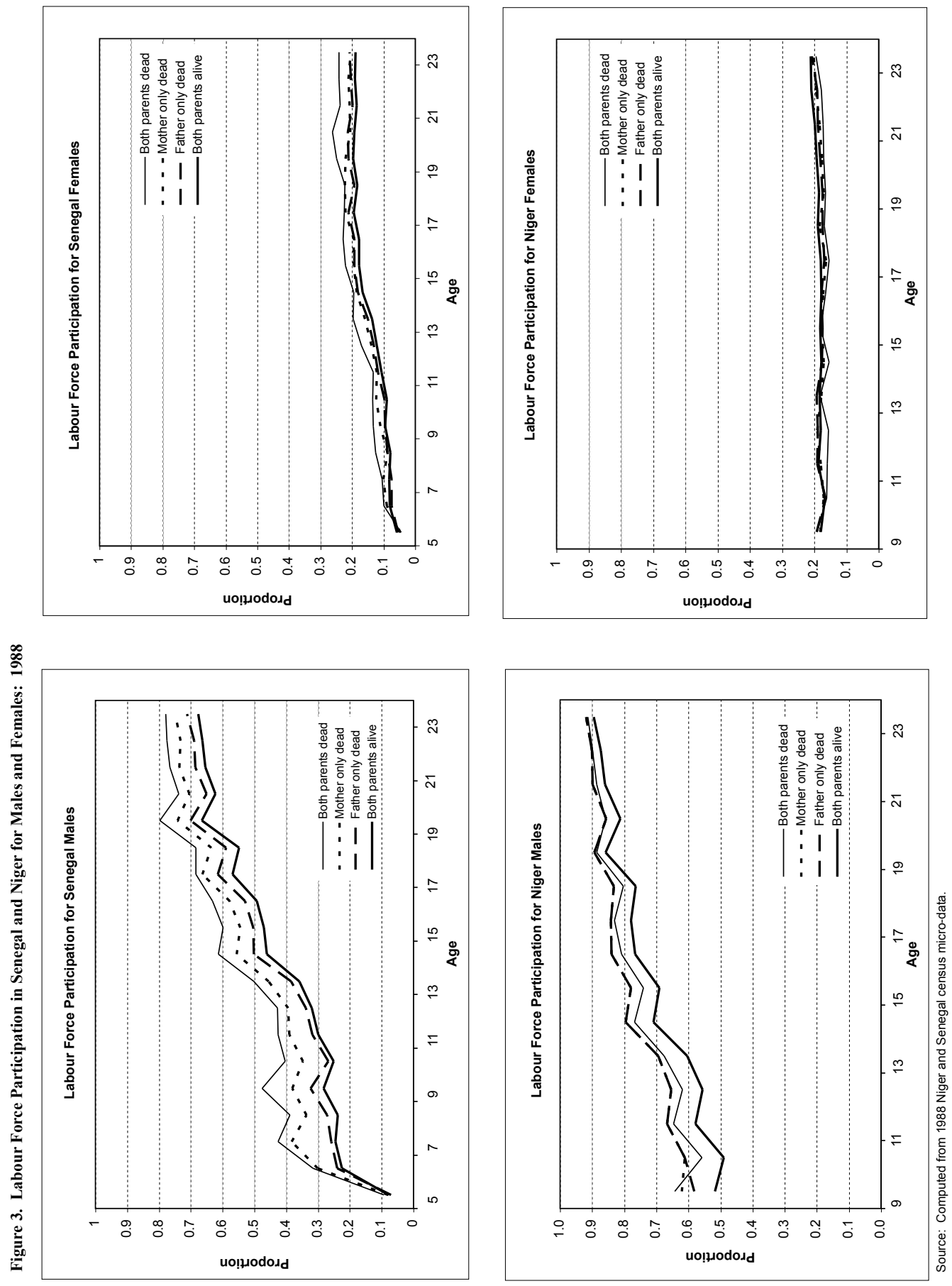

CSP 2010, 37.1-2: 245-267 


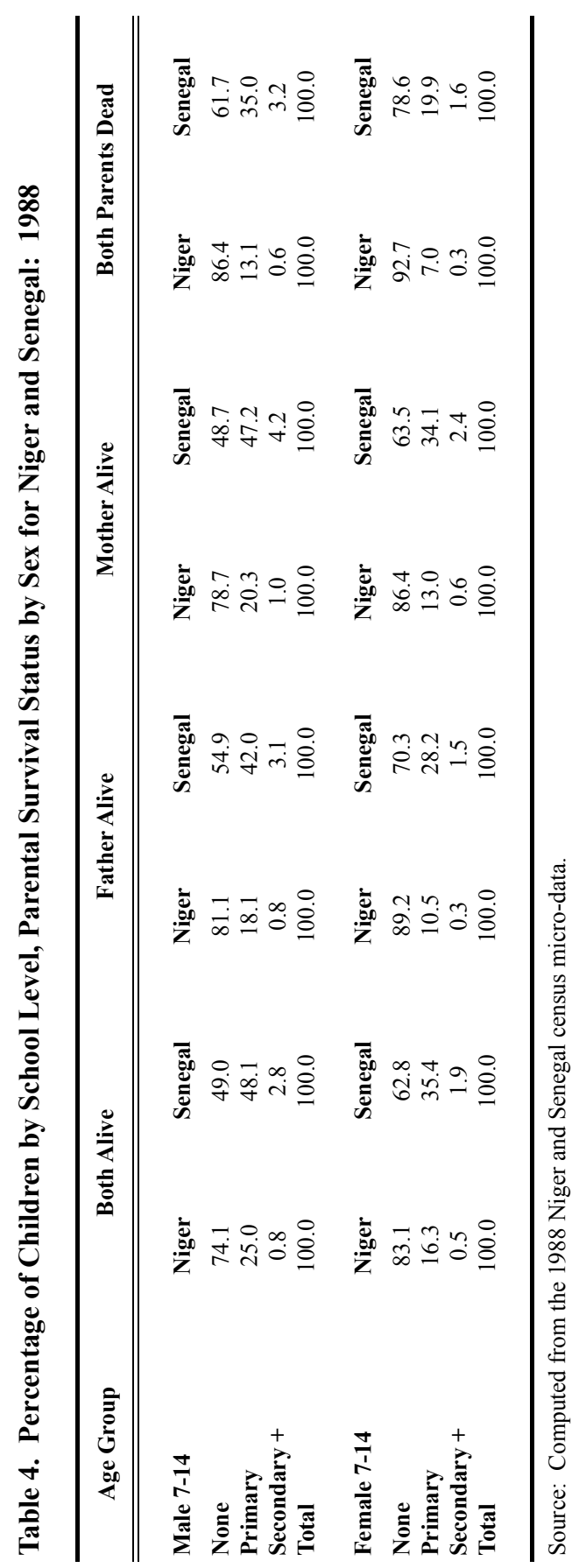


children start working at a much younger age when they are orphans: in Senegal, the difference is close to $20 \%$ between ages 7 and 12 and diminishes slightly afterwards. We observe essentially the same phenomenon in Niger, but with much smaller differences between orphans and non-orphans.

For girls, we observe the same trends in Senegal, while in Niger the curves overlap at almost all ages, suggesting that losing a parent has no effect on labor market entry for young women in Niger. However, this may be due to the difficulties of empirically capturing women's labor in this country. These results suggest more specifically the limits of census data for defining women's participation in productive activities, notably in settings where agricultural subsistence economies dominate. Women's economic activity seems to be better captured in areas where a market economy predominates. Thus, the urban labor market is well suited to a more detailed analysis of women's economic activity.

We then focus our analysis of urban labor markets by singling out the capitals of the countries in order to examine the employment structures of young workers according to the survival of their parents. Comparative analysis of data, not present here, reveals first of all that concepts related to the employment status of young people less than 15 years old are probably used differently. In the informal sectors that incorporate child labor, it can sometimes be difficult to distinguish clearly between the statuses of independent worker and salaried worker among those less than 15 years old. Similarly, in the real world of child labor the boundaries of the categories "apprentice" and household helper can occasionally overlap. It is reasonable to think that salaried workers and independent workers more often enter into relatively autonomous work relationships, while the activities of apprentices and household helpers are more often carried out within the confines of family group activities and under the supervision of a family member. This distinction between, on the one hand, autonomous labor evoked by the statuses of independent and salaried workers and, on the other hand, work relating to activities that are part of family economic activities, seems to be fundamental in child labor laws that aim to limit the risks of exploitation of children younger than 15 years old (BIT 1987; Myers 1992; Marcoux 1995).

Using this distinction, we note that the data for the capitals illustrate very different processes of insertion into the labor market according to the survival status of the parents. Among those under age 15, the proportion of independent and salaried workers is generally higher among children who have lost both parents than among those whose parents are both alive. On the other hand, these latter, when they work, are more likely to do so as apprentices or household helpers. For older children, we again observe distinct patterns of insertion into the labor market according to the survival of parents. On the whole, double orphans seem to be in the labor market as independent workers more often than those who can rely on two surviving parents. This phenomenon is observed 
Orphans in Three Sahelian Countries:

Exploratory Analysis from Census Data

among both girls and boys and for both capitals and the two oldest age groups.

\section{Conclusion: A Distinct Life Cycle for Orphans?}

The data analyzed show that the phenomenon of orphanhood is far from negligible in the Sahel. While attention directed at orphans is often focused on the countries where the AIDS pandemic is most widespread-southern Africa, South Africa, and the Great Lakes region of Africa-we note that between $30 \%$ and $35 \%$ of young Sahelians experienced the death of at least one parent before age 25. Taking into account gender differences in age at marriage and life expectancy found in this sub-region, the loss of a parent often means, first and foremost, the loss of the father: at age 24 , almost $80 \%$ of the young people who have lost at least one parent are paternal orphans. There is no doubt that this result alone could inspire numerous reflections on the place of the father in Sahelian societies.

Examining family ties shows us the importance of family support networks, since the vast majority of children who have lost a parent are still related to the head of their household. In addition, we would like to point out that young female orphans in Niger are more likely than boys to live in households where they have no family tie to the head of household. This circulation of children outside of family networks, which differs according to the sex of the children, should certainly be further studied in future research.

The two dimensions of social insertion that we have examined here lead us to the conclusion that the death of parent weighs heavily on children's future. Orphans go to school less often than children whose parents are alive, and orphans achieved lower levels of schooling. Similarly, orphans seem to enter the labor market earlier and are more likely to work as autonomous workers, thus deprived of the family environment that might protect them from the abusive situations that characterize some sectors of the market economy.

The loss of death parents seems to lead children to specific academic and professional pathways and produces a distinct family life course for orphans. The results of the following figure lead us to realize that the death of parents seems to be associated with a much earlier exit from singlehood for both sexes. The results for young Senegalese girls are particularly striking: at age 18 almost $60 \%$ of girls whose parents are alive are still single, while the proportion is only around $25 \%$ for girls who are double orphans.

These initial exploratory analyses give rise to more questions than they bring answers. We know that what happens to children is closely linked to what happens to their parents. The extended family safety net in Africa may have been strongly shaken by the economic difficulties experienced in the Sahel over the past thirty years. This, at least, is the conclusion suggested by our exploratory study on orphans. Census data, although flawed, are demonstrated 
Richard Marcoux, Amadou Noumbissi and Tukufu Zuberi
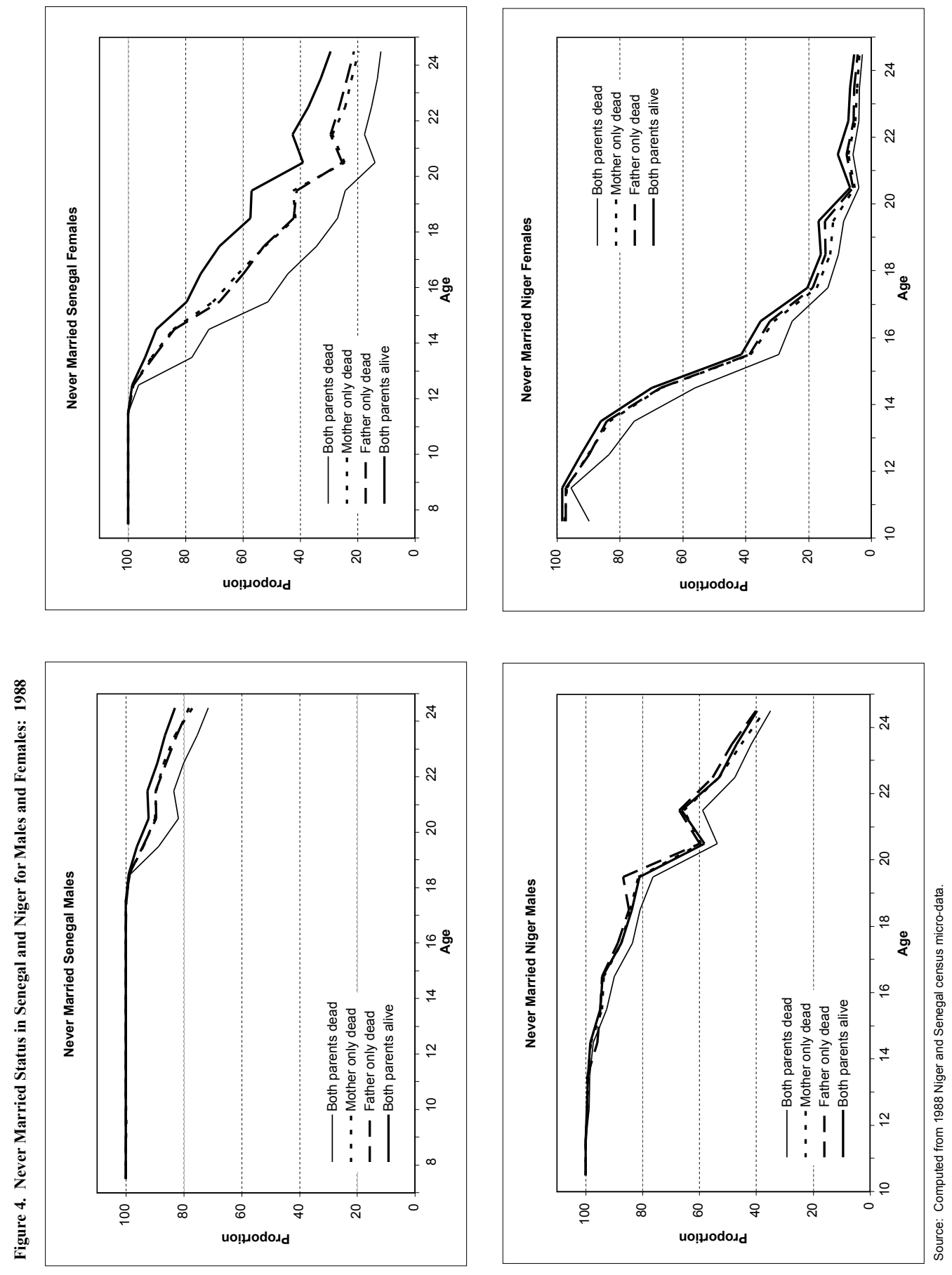

CSP 2010, 37.1-2: 245-267 
Orphans in Three Sahelian Countries:

Exploratory Analysis from Census Data

to be very useful for the study of a population that is numerically fairly marginal but that, unfortunately, will likely show substantial growth in the coming years.

\section{Acknowledgements}

This research was done as part of African Census Analysis Project (ACAP) of University of Pennsylvania. ACAP is supported by grants from the Rockefeller Foundation (RF 97013 \#21; RF 98014 \#22), the Andrew W. Mellon Foundation, and the Fogarty International Center and the National Institute of Child Health and Human Development (TW00655-04). The authors also acknowledge the financial support provided by the Social Sciences and Humanities Research Council of Canada (SSHRC) and would like to thank Timothy Cheney and Fatou Dia for computer assistance. Research for this article was conducted while Dr. Amadou Noumbissi was a Research Associate with the African Census Analysis Project (ACAP) at the University of Pennsylvania, but he sadly did not live to see its publication. Dr. Noumbissi passed away peacefully on 29 November 2005; however, his contribution was essential for the realization of this article that we dedicated to his memory. Responsibility for any errors rest with the authors.

\section{End Notes}

1. From Webster's "a child deprived by death of one or usually both parents..."

2. For the following more detailed analysis, we have excluded Chad because of the lack of good data on key variables such as relationship to the household head, education and labour force participation, retained for this paper.

CSP 2010, 37.1-2: 245-267 


\section{References}

Antonielli, Albert. 1993. Le droit d'apprendre. Une école pour tous en Afrique. Paris: L'Harmattan.

Ayad, Mohamed. 2002. "Mortalité maternelle," in Enquête démographique et de santé, Mali, 2001. Calverton, Maryland: CPS/MS, DNSI and ORC Macro. Pp. 177-186.

Ba, Souleymane and Boureima Singare. 2002. "Mortalité des enfants," in Enquête démographique et de santé, Mali, 2001. Calverton, Maryland: CPS/MS, DNSI and ORC Macro. Pp. 165-176.

Bah, Sulaiman.1999. "Diagnostic tests on assessing the quality of maternal orphanhood data from the 1996 South African census and implications for the indirect estimation of adult mortality." Discussion Paper 99-5. London, Ontario: University of Western Ontario, Canada.

Barère, Monique and Bernard Barère, 1998. "La Mortalité des enfants," in Enquête démographique et de santé, Tchad, 1996-1997. Calverton, Maryland: BCR, DSEED/MPAT and ORC Macro. Pp. 151-162.

Bicego, G., Shea Ruststein, and Kirsten Johnson. 2003. "Dimensions of the emerging orphan crisis in sub-Saharan Africa." Social Science and Medicine 56: 1235-1247.

Brass, William and K. Hill. 1973. Estimating adult mortality from orphanhood. UIESP, Congrès de Liège, $3: 111-123$.

Bureau International du Travail (BIT). 1987. Le travail des enfants: Manuel d'information. Geneva: BIT.

Caldwell, John C. 1997. "The Impact of the African AIDS Epidemic." Health and Transition Review, Supplement to volume 7: 169-188.

Case A., C. Paxson and J. Ableidinger. 2002. Orphans in Africa. Working Paper 9213. National Bureau of Economic Research. Cambridge.

Coulibali, Ishaga, and Boureima Singare. 2002. "La Fécondité; Enquête démographique et de santé, Mali, 2001." Calverton, Maryland: CPS/MS, DNSI and ORC Macro. Pp. 43-56.

CSP 2010, 37.1-2: 245-267 
Orphans in Three Sahelian Countries:

Exploratory Analysis from Census Data

Crenson, Matthew A. 1998. Building the Invisible Orphanage. A Prehistory of the American Welfare System. Cambridge, MA: Harvard University Press.

Hill, K. and J. Trussell. 1977. "Further developments in indirect mortality estimation.” Population Studies 31(2): 313-334.

Hunter, S. and J. Williamson. 1999. Children on the brink, Strategies to support children isolated by HIV/AIDS. Washington, DC: The Synergy Project of TvT Associates, Inc. HIV-AIDS Division of USAID.

.2000. Children on the brink, Updated estimates and recommendations for intervention. Washington, DC: The Synergy Project of TvT Associates, Inc. HIV-AIDS Division of USAID.

Koven, S. and S. Michel, (eds.) 1993. Mothers of a New World: Maternalist Politics and the Origins of Welfares States, 1917-1942. New York: Routledge.

Lee, Nick. 2001. "Being in their own right? The recognition and mis-recognition of children," in Childhood and Society. Growing up in Age of Uncertainty. Nick Lee (ed.), London: Open University Press. Pp. 36-54.

Légaré, Jacques and Domonic Duford. 2001. "La prise en charge des orphelins de père et de mère en Nouvelle-France au 18ième siècle: une étude exploratoire," in Famille, parenté et réseaux en Occident. A.L HeadKonig et al.(eds.), Société d'Histoire et d'archéolgie de Genève. Pp. 119-133.

Marcoux, Richard. 1997. "Le travail, un jeu d'enfant? À propos de la contribution des enfants à la subsistance des ménages au Mali," in Ménages et familles en Afrique: Approches des dynamiques contemporaines. M. Pilon, T. Locoh, E. Vignikin et P. Vimard (eds.), Paris: Éditions du CEPED. Pp. 209-222.

Marcoux, Richard. 1994. "Des inactifs qui ne chôment pas: une réflexion sur le travail des enfants en milieu urbain au Mali." Travail, capital et société 27(2): 226-319.

Marcoux, Richard. 1995. "Fréquentation scolaire et structure démographique des ménages en milieu urbain au Mali." Cahiers des Sciences humaines 31(3): 655-674.

CSP 2010, 37.1-2: 245-267 
Marcoux, Richard. 1998. "Entre l'école et la calebasse. Sous-scolarisation des filles et mise au travail à Bamako," in L'école et les filles en Afrique, by Marie-France Lange (ed.), Paris: Karthala. Pp. 73-96

Marcoux, Richard, Mouhamadou Gueye, and Mamadou Kani Konaté. 2002. Environnement familial, itinéraires scolaires et travail des enfants au Mali. Colloque international Enfants d'aujourd'hui. Diversité des contextes, pluralité des parcours, l'Association internationale des démographes de langue française (AIDELF), Dakar, décembre 2002.

Mboup, Gora. 1998. "La Mortalité des enfants de moins de 5 ans," in Enquête démographique et de santé, Burkina Faso, 1998-1999. Calverton, MD BCR, INSD/MEF and ORC Macro. Pp. 135-144.

McDaniel, Antonio and Eliya Zulu. 1996. "Mothers, fathers and children: regional patterns in child-parent residence in Sub-Saharan Africa." African Population Studies 11: 1-28.

Murray, John E. 2003. "Fates of orphans: Poor children in Antebellum Charleston." Journal of Interdisciplinary History 33(4): 519-545.

Myers, William E. 1992. "Introduction," Protéger les enfants au travail. New York, UNICEF. Pp. 15-23.

Nardinelli, Clark. 1990. Child Labor and the Industrial Revolution. Bloomington, IN: Indiana University Press.

Njoniri, Joel Nojimbatem. 1998. "La Fécondité," in Enquête démographique et de santé, Tchad, 1996-1997. Calverton, MD: BCR, DSEED/MPAT and ORC Macro. Pp. 37-54.

Quinn, C. Thomas. 2001. "AIDS in Africa: a retrospective." Bulletin of the World Health Organization 79 (12): 1156-1167.

Sullivan, Jeremiah and Bernard Barère. 1993. "La Mortalité maternelle," in Enquête démographique et de santé, Niamey, 1992. Calverton, MD and DSCN/DGP Ministère des Finances et du Plan and ORC Macro. Pp. 145-154.

Timaeus, Ian M. 1992. "Estimation of mortality paternal orphanhood: A reassessment and new approach." Population Bulletin of the United Nations 33: 47-63.

CSP 2010, 37.1-2: 245-267 
Orphans in Three Sahelian Countries:

Exploratory Analysis from Census Data

Turmel, André. 2008. A Historical Sociology of Childhood: Developmental

Thinking, Categorization, and Graphic Visualization. Cambridge, MA:

Cambridge University Press.

United Nations. 2000. The World's women 2000, Trends and statistics. Social Statistics and Indicators, Series K. No. 6, New York.

Wakam, Jean. 2002. "La situation des enfants orphelins en matière de scolarisation en Afrique: Le cas du Cameroun," in Jeunesses et vieillesses et sociétés. F. Gendreau and D. Tabutin (eds.), Louvain-laNeuve: EditionsAcademia/L'Harmattan. Pp.177-195. 